\title{
ДЕЯКІ ПИТАННЯ ДУХОВНО-ІНТЕЛЕКТУАЛЬНОГО ВИХОВАННЯ ДІТЕЙ У ВІТЧИЗНЯНІЙ ПЕДАГОГІЧНІЙ СПАДЩИНІ НА ПОЧАТКУ ХХ СТОЛІТТЯ
}

\author{
Ялліна В. Л. \\ кандидат педагогічних наук, доцент, доцент кафедри освітології та \\ інноваційної педагогіки, Харківський національний педагогічний \\ університет імені Г. С. Сковороди, м. Харків, Україна
}

У статті аналізуються історико-педагогічні дослідження вітчизняних діячів освіти початку XX століття з проблем духовно-інтелектуального виховання дитини. Представлено погляди видатних вітчизняних учених (О. Музиченко, С. Русова, Я. Чепіга та ін.) на питання, що пов 'язані з інтелектуально-духовним вихованням дитини.

Ключові слова: розум, духовність, виховання, мислення, дитина

In the article are analysed the historic-pedagogical researches of Ukrainian scientists in the problem of mental and intellectual education of the begining of XX century. The basic approaches to mental and intellectual education of the children's person in the view of domestic pedagogical scientists (0. Muzychenko, S. Rusova, Y.Chepiga and others) are presented

Key words: intellect, mental, education, thinking, child

На сучасному етапі розвитку суспільства головним пріоритетом постає формування соціально активної, високоморальної та інтелектуально-творчої особистості. Саме тому актуальним залишається звернення до історико-педагогічного досвіду. Так, на початку ХХ століття у громадсько-педагогічних колах активно дискутувалися проблеми щодо реформування освітньої системи відповідно до вимог часу. Педагогічну громадськість турбувало формування такої школи, яка була б спрямована на розвиток індивідуальних особливостей дітей, їхнього мислення та самостійності, прищеплення вихованцям високих духовно-моральних якостей. Школа критикувалася за їі безініціативність, перевантаженість учнів, низький рівень кваліфікації частини педагогічного персоналу, відсутність координації зусиль сім’і, школи. Нові педагогічні течії, що виникли під впливом реформаторської педагогіки, прагнули розвивати розумові здібності особистості не шляхом накопичення знань, а шляхом розвитку дитячого мислення. 
Розділ III. Історичні та порівняльні аспекти в теорії і практиці духовно-інтелектуального виховання й навчання

Ще у 1900 році директор Києво-Печерської гімназії В. Петр у брошурі «Про завдання середньої школи» (1900р.) [10] зазначав, що середня школа має досягти двох цілей: «збагачення розуму та розвитку благородства душі й серця у своїх вихованців». У цей період здійснюються дослідження про природу дитинства, на педагогічних з'їздах обговорюється практичний досвід ряду навчальних закладів, зміст педагогічних досліджень з питань розумової роботи дитини, визначаються фактори, що впливають на розвиток дитячої пам'яті, їхніх почуттів, уявлень, розглядаються проблеми розумової перевтоми, складання шкільних характеристик, правильної організації навчальновиховної роботи [3; 9].

Про взаємозвязок розумового розвитку і почуттів писав у своїх лекціях з педагогіки професор Н.Грунський, який зазначав, що мистецтво правильно міркувати разом з тим може бути й початком розвитку нашого морального почуття [4].

Питання духовно-інтелектуального виховання знайшли належне місце і у науковому доробку українських педагогів початку ХХ століття: І. Сікорського, О. Музиченка, С. Русової, Я. Чепіги та інших. Так, відомий український педагог I. Сікорський вважав, що результатом правильного виховання має бути гармонійний розвиток духу і тіла, розуму, почуття і волі. Він застерігав від домінування у розвитку однієї зі сторін. Важливим, на думку вченого, було дослідження особливостей дітей, психологічного стану, педагогічних впливів. Він вивчав значення процесів мислення школярів для загального розумового розвитку особистості, вплив розумової втоми на навчальну діяльність [13]. Окреме місце у його спадщині займало вивчення проблеми розумової відсталості дітей.

Аналізуючи погляди О. Музиченка на духовно-інтелектуальне виховання слід зазначити, що формування духовності людини він убачав через науку, мистецтво, мораль і релігію. На його думку, саме освіта формує правильний погляд на світ, виховує характер людини, збуджуючи усі інтереси рівномірно [8]. Під час організації освітнього процесу педагог звернув увагу на необхідність пробудження думки, розвиток мислення; розумову працю. Крім того, учений наполягав на необхідності створення атмосфери пошуку. [14, С. 449].

Про важливість у школі зробити виховання спрямованим до наукового мислення наголошував С. Ананьїн, який у тому числі підкреслю- 
вав необхідність підготувати «людину, яка б змогла на основі наукового мислення виявити свою інтелектуальну самодіяльність у будь-якій галузі знань, життя і діяльності» [1]. Науковець організував дослідження 3 питань моральних і освітніх ідеалів молоді серед учнів старших класів жіночих і чоловічих гімназій.

Вивчення праць відомого педагога, методиста Т. Лубенця показало, що у центрі його уваги були також питання духовно-інтелектуального виховання. Він зазначав, що завданнями школи є розвиток розумових здібностей і моральних якостей учнів. Педагог, розглядаючи питання інтелектуального виховання, вказував на важливість надання знань, їх практичне значення, розвиток розумової активності через навчання. [5; 6, С. 71-72]. Т. Лубенець обгрунтував методи та засоби навчання, що спрямовані на розвиток інтересу, уваги, пам'яті. [6, С.261, 264]. Крім того, педагог не оминув питання ролі вчителя у духовноморальному розвитку дитини, необхідності знання природи дитини, іiі емоційної та духовної сфери, врахування впливу навколишнього середовища на дитину.

Слід зазначити, що О. Водовозова розглядала ідеал виховання як створення здорової людини з твердою волею, розумово і морально розвиненої. У цьому контексті важливо розвивати здібності, стримувати пагубні спадкові нахили, пробуджувати цікавість, прагнення до самовдосконалення, до постійного розширення розумового кругозору. Педагог підкреслювала необхідність виховання з раннього дитинства волі й характеру, які є джерелом розумового самовдосконалення, розвитку в дитини віри у власні сили [2].

Аналіз творчої спадщини С. Русової показав, що, на їі думку, у розвитку і формуванні особистості основне місце посідають розумове, моральне, естетичне, трудове і фізичне виховання, а також розвиток творчих здібностей, нахилів учнів. Так, духовно-моральне виховання дітей залежить від створеної у школі атмосфери спілкування, а також вихованні у родині, у врахуванні народних традицій і ідеалів.

Правильно організоване інтелектуальне виховання, на думку С. Русової, забезпечує підвищення загального рівня розвитку дитини, збудження в неї духовних сил. Педагог головним завданням розумового виховання вважала засвоєння учнями наукових знань про природу, суспільство і людину; оволодіння основними розумовими операціями; формування інтелектуальних умінь і наукового світогляду [11]. С. Русова обгрунтову- 
вала необхідність використовувати нові методи навчання й виховання, забезпечувати розвиток природних творчих здібностей і задатків кожної дитини, розвивати самостійність, творчі сили. [12, С. 4].

Відомий український педагог Я.Чепіга розглядав у єдності інтелектуальне і духовне виховання. Так, на його думку, розумове виховання відбувається у процесі здобуття наукових знань, але не зводиться лише до нагромадження певного їх обсягу [17]. Учений наголошував, що багатство всього духовного життя, загальний рівень розвитку вчителя, зміст навчальних програм, характер методів навчання, організація розумової праці учнів на уроках і вдома сприятимуть розумовому вихованню $[15 ; 16]$. На думку Я.Чепіги, духовно-моральні уявлення формуються у дитини ще у родині, на змісті народної культури, оволодінням рідною мовою. Завдання педагога полягає також і у розвитку духовних якостей дитини. Він доводив необхідність глибоко вивчати природу дитини, їі духовний і фізіологічний розвиток, враховувати під час навчання індивідуальні природні здібності дитини.

На важливості розвитку духовних здібностей, вольових зусиль, організації добрих вчинків дітей наголошував С.Миропольський. Педагог підкреслював важливість збудження допитливості дітей в якомога більшій кількості напрямів. Крім того, він зазначав, що вчитель має не заважати розвиткові й виявленню інтелектуальних інстинктів дитини та давати учневі той матеріал, який би сприяв правильному вихованню. [7, с. 135-140].

Таким чином, на початку XX ст. педагогічна думка України була спрямована на створення нової школи, основними засадами якої були активність і творчість учнів. Учені звернули увагу на важливість індивідуального підходу до дитини, вивчення ії природних здібностей, розвитку мислення, інтересу, моральних почуттів, формування світогляду, врахування народних традицій і ідеалів, активного використання рідної мови, значення особистості педагога та ролі сімї у духовноінтелектуальному вихованні.

\section{Список використаних джерел}

1. Ананьин С. А. Очерки по педагогике средней школы Журнал Министерства народного просвещения 1914 янв С. 88-89

2. Водовозова Е. Н. Умственное и нравственное воспитание детей от первого проявления сознания до школьного возраста [7-е изд., перераб. и доп.] Санкт-Петербург., 1913. - 365 с. 
3. Второй Всероссийский съезд по педагогической психологии Воспитание и обучение. 1909. № 10. С. 292-297

4. Грунский Н. К. Лекции по педагогике. Юрьев., Типографія Н.Маттисена. 1908. $291 \mathrm{c}$

5. Лубенець Т. Які вимоги пред’являє народ школі Известия по народному образованию. 1912. Ч. 33 (апрель). С. 71-72

6. Лубенець Т. Г. Педагогічні бесіди Антологія педагогічної думки Української РСР. М., 1988. С. 322

7. Миропольский С. Учитель, его призваніе и качества, значеніе, цђли и условія его дђятельности въ воспитаніи и обученіи дђтей СанктПетербург:: Типографія Глазунова, 1909. 148 с.

8. Музыченко А. Ф. Какой должна быть школа? Народная энциклопедия научных и прикладных знаний. Москва: Тип. т-ва И. Д. Сытина, 1911. T. 9. С. $157-171$.

9. Первый Всероссийский съезд по вопросам семейного воспитания // Русская школа . 1912. № 5-6. С. 129-133

10. Петр В. И. О задачах средней школы Киев, 1900. 8 с.

11. Русова С.. Ідейні підвалини школи Світло. 1913. Кн. 8. С. 33-38.

12. Русова С. Нова школа Світло. 1914 Кн. 7-8. С. 3-16.

13. Сикорский И. Об умственном и нравственном развитии учащихся в средней школе в святи с здравоохранением Вопросы нервно-психической медицины. 1901. T.VI. С. 103-138.

14. Труды Киевского педагогического съезда. 12-19 апреля 1916 г. Киев : Типогр. Тов-ва И. Н.Кушнарева и К, 1916. 768 с

15. Чепіга Я. Увага і розумовий розвиток дитини Світло. 1911. Кн. І. С. 20-33.

16. Чепіга Я. Самовиховання вчителя Світло. 1913. Кн. 8. С. 9-18; Кн. 9. C. 6-13.

17. Чепіга Я. Ф. Проблеми виховання й навчання в світлі науки й практики : Збірник психо-педагогічних статей. Кн. 1-ша. К.,1913. 157 с. 